\title{
PENERAPAN SANKSI PIDANA BERDASARKAN UNDANG-UNDANG NO. 7 TAHUN 2017 TENTANG PEMILU TERHADAP PERINDO KARENA"CURI START" KAMPANYE DALAM PEMILU 2019
}

\author{
Edison Hatoguan Manurung \\ edisonmanurung2010@yahoo com \\ Program Doktor UTA45 Jakarta \\ Ina Heliany \\ Inaheliany6@gmail.com \\ Pasca Sarjana Universitas Mpu Tantular
}

\begin{abstract}
ABSTRAK
Menurut Undang Nomor 7 Tahun 2017 Tentang Pemilihan Umum dinyatakan bahwa pemilihan umum selanjutnya disebut Pemilu adalah sarana pelaksanaan kedaulatan rakyat yang dilaksanakan secara langsung, umum, bebas, rahasia, jujur, dan adil dalam Negara Kesatuan Republik Indonesia berdasarkan Pancasila dan Undang-Undang Dasar Negara Republik Indonesia Tahun 1945. Dalam penyelenggaraan pemilu banyak sekali ditemukan pelanggaran.Tak heran jika Bawaslu Pusat maupun Panwaslu di daerah-daerah memiliki segudang bukti pelanggaran baik yang dilakukan oleh penyelenggara, peserta,dan pelaksana pemilu. Salah satunya adalah mengenai kasus Partai Perindo yang telah melakukan kampanye di luar jadwal yang sudah ditetapkan atau bisa dikatakan telah "mencuri start". Berkaitan dengan keterangan diatas maka penelitian ini akan menguraikan tentangbagaimanakah peran Bawaslu terhadap pelanggaran kampanye yang dilakukan oleh partai Perindo serta bagaimana penerapan sanksi pidana terhadap partai yang telah melakukan pelanggaran kampanye berdasarkan Undang-undang Pemilu. Metode pendekatan yang digunakan dalam penelitian ini adalah metode pendekatan yuridis normatif, spesifikasi penelitian yang digunakan yaitu deskriptif. Penarikan kesimpulan dari hasil penelitian yang sudah dikumpulkan dilakukan dengan metode analisis normatif kualitatif. Normatif yaitu mempergunakan sumber-sumber data sekunder saja yaitu peraturan perundang-undangan, teori-teori hukum dan pendapat-pendapat para sarjana hukum terkemuka. Dalam penelitian ini sebagaimana pasal 93,94,95 UU Pemilu diketahui bahwa Bawaslu berperan untuk menerima laporan dan menindak lanjutinya, sehingga didapati bahwa Perindo sudah melakukan pelanggaran pemilu hal ini merupakan laporan dari KPI, karena Perindo telah berkampanye, dengan cara menayangkan Mars Perindo di stasiun TV milik HTS . Terkait pelanggaran yang dilakukan Perindo, maka HTS dikenakan pasal 492 Undang-Undang Nomor 7 Tahun 2017 tentang Pemilihan Umum.
\end{abstract}

Kata Kunci : Sanksi Pidana; Pemilu dan Kampanye 


\title{
APPLICATION OF CRIMINAL SANCTIONS BASED ON LAW NO. 7 OF 2017 ABOUT ELECTIONS AGAINST PERINDO BECAUSE "CURI START" CAMPAIGN IN 2019 ELECTION
}

\author{
Edison Hatoguan Manurung \\ edisonmanurung2010@yahoocom \\ Doctoral Program in UTA45 Jakarta \\ Ina Heliany \\ Inaheliany6@gmail.com \\ Post-graduate of Mpu Tantular University
}

\begin{abstract}
According to Law Number 7 of 2017 concerning General Elections, it is stated that the general election hereinafter referred to as the Election is a means of implementing popular sovereignty which is carried out directly, publicly, freely, confidentially, honestly and fairly in the Unitary State of the Republic of Indonesia based on Pancasila and the Constitution of the Republic of Indonesia Indonesia in 1945. There were a lot of violations in the implementation of elections. No wonder the Central Election Supervisory Body and the Election Supervisory Committee in the regions had a myriad of evidence of violations committed by the organizers, participants, and executors of the election. One of them is the case of the Perindo Party which has carried out a campaign outside the schedule that has been set or can be said to have "stolen the start".In connection with the above information, this research will describe the role of the Election Supervisory Body on campaign violations committed by the Perindo party and the application of criminal sanctions against parties that have committed campaign violations based on the Election Law. The approach method used in this research is the normative juridical approach, the research specification used is descriptive. Withdrawal of conclusions from the results of research that has been collected is done with qualitative normative analysis method. Normative is to use secondary data sources, namely laws and regulations, legal theories and opinions of prominent law scholars. In this study as article 93,94,95 the Election Law is known that Bawaslu has a role to receive reports and follow up on it, so that Perindo has committed election violations this is a report from KPI, because Perindo has campaigned, by showing Mars Perindo at the station TV owned by HTS. Regarding violations committed by Perindo, HTS is subject to Article 492 of Law Number 7 of 2017 concerning General Elections.
\end{abstract}

Keywords: Criminal Sanctions; Elections and Campaigns 


\section{A. LATAR BELAKANG}

You can have election without demoracy, but you can not have democray without election. Kalimat tersebut menunjukkan betapa pemilu sangat penting bagi negara yang menjalankan sistem demokrasi. Pemilihan umum (pemilu) di Indonesia sendiri pada hakekatnya merupakan sarana pemenuhan demokrasi dari suatu negara, yakni perwujudan dari asas kedaulatan rakyat sebagaimana rumusan Pasal 1 ayat (2) Undang Undang Dasar Negara Kesatuan Republik Indonesia Tahun 1945. Menurut ketentuan Pasal 1 butir 1 Undang Undang Nomor 7 Tahun 2017 Tentang Pemilihan Umum dikatakan, bahwa pemilihan umum selanjutnya disebut Pemilu adalah sarana pelaksanaan kedaulatan rakyat yang dilaksanakan secara langsung, umum, bebas, rahasia, jujur, dan adil dalam Negara Kesatuan Republik Indonesia berdasarkan Pancasila dan Undang-Undang Dasar Negara Republik Indonesia Tahun 1945.

Menarik bahwa dalam penyelenggaraan pemilu yang mulai dari tahapan awal, pendaftaran calon peserta pemilu dan calon pemilih, kemudian dilanjutkan dengan penetapan calon peserta dan pemilih, dan pelaksanaan kampanye hingga waktu pencontrengan, penuh dengan intrikintrik politik atas dasar sensifitas politik masing-masing peserta pemilu. Tak heran jika Bawaslu Pusat maupun Panwaslu di daerah-daerah memiliki segudang bukti pelanggaran baik yang dilakukan oleh penyelenggara, peserta, pelaksana pemilu, dan pemerintah serta lembaga peradilan hingga masyarakat umum. Ironisnya, dari sekian pelanggaran yang dilakukan, terlihat hanya beberapa kasus saja yang diproses melalui jalur hukum, itupun jika pelanggaran tersebut menjadi opini publik, padahal dari beberapa kasus yang motif dan modus operandinya sama diberbagai daerah, ada yang justru tidak diselesaikan melalui jalur hukum, sehingga terkesan bersifat "disparitas" atau juga diskriminatif.

Diantara sekian banyak kasus pelanggaran pemilu yang terjadi hampir di seluruh Indonesia, yang menarik untuk diperbincangkan adalah kasus Partai Perindo yang merupakan partai baru peserta pemilu yang telah melakukan 
kampanye di luar jadwal yang sudah ditetapkan atau bisa dikatakan telah "mencuri start". Berdasarkan aturan untuk pemilihan legislatif maupun pemilihan presiden, kampanye baru dimulai pada 23 September 2018. Namun Bawaslu melaporkan dugaan pelanggaran yang dilakukan Perindo terkait empat media MNC Group (RCTI, MNC TV, Global TV dan I News) yang telah melakukan kampanye melalui media elektronik sejak tanggal 2 Maret 2018. Ketua Badan Pengawas Pemilu (Bawaslu), Abhan, mengingatkan, partai politik (Parpol) peserta pemilu 2019 tidak boleh melakukan aktivitas kampanye di luar jadwal yang sudah ditetapkan, pasalnya, siapapun yang terbukti melakukan kampanye di luar jadwal, bisa dikenai sanksi pidana. Aturan ini secara tegas sudah tertuang dalam Undangundang No 7 Tahun 2017 Tentang Pemilu, akan tetapi berlakunya Undangundang ini masih saja tidak ditaati oleh partai para peserta pemilu bahkan hanya dianggap angin lalu. Berkaitan dengan keterangan diatas maka penelitian ini akan menguraikan tentang bagaimanakah peran Bawaslu terhadap pelanggaran kampanye yang dilakukan oleh partai Perindo ? serta bagaimana penerapan sanksi pidana terhadap partai yang telah melakukan pelanggaran kampanye berdasarkan Undang-undang Pemilu?

\section{B. PERUMUSAN MASALAH}

1. Bagaimanakah peran Bawaslu terhadap pelanggaran kampanye yang dilakukan oleh partai Perindo ?

2. Bagaimana penerapan sanksi pidana terhadap partai yang telah melakukan pelanggaran kampanye berdasarkan Undang-undang Pemilu?

\section{METODOLOGI PENELITIAN}

Metode pendekatan yang digunakan dalam penelitian ini adalah metode pendekatan yuridis normatif, spesifikasi penelitian yang digunakan yaitu deskriptif. Penarikan kesimpulan dari hasil penelitian yang sudah dikumpulkan dilakukan dengan metode analisis normatif kualitatif. Normatif yaitu mempergunakan sumber-sumber data sekunder saja yaitu peraturan perundang-undangan, teori-teori hukum dan pendapat-pendapat 
para sarjana hukum terkemuka. ${ }^{1}$ Kualitatif karena merupakan proses analisis data tanpa menggunakan rumus dan angka-angka yang berasal dari informasi-informasi hasil studi kepustakaan yaitu data yang diambil dari instansi-instansi terkait maupun hasil pengamatan dalam penelitian yang dilakukan dengan masalah yang dibahas tersebut.

\section{TINJAUAN TEORITIK}

1. Pengertian sanksi

Sanksi berasal dari bahasa Belanda yaitu Sanctie, seperti dalam poenale sanctie yang terkenal dalam sejarah Indonesia pada masa kolonial Belanda. ${ }^{2}$ Sanksi sendiri dapat diartikan sebagai ancaman hukuman, yang merupakan suatu alat pemaksa guna ditaatinya suatu kaidah undang-undang misalnya sanksi terhadap pelanggaran suatu undang-undang. ${ }^{3}$ Pengertian sanksi sendiri dalam KBBI adalah tindakan-tindakan (hukuman) untuk memaksa seseorang menaati aturan atau menaati ketentuan undang-undang . ${ }^{4}$ Sanksi adalah alat pemaksa, dimana sanksi memaksa menegakkan hukum atau memaksa mengindahkan norma-norma hukum. Sanksi sebagai alat penegak hukum bisa juga terdiri atas kebatalan perbuatan yang merupakan pelanggaran hukum. Baik batal demi hukum maupun batal setelah ini dinyatakan oleh hakim.$^{5}$

Sanksi dalam hukum pidana terbagi atas dua yaitu : sanksi pidana dan sanksi tindakan. Sanksi pidana sesungguhnya bersifat reaktif terhadap suatu perbuatan, sedangkan sanksi tindakan lebih bersifat antisipatif terhadap pelaku perbuatan tersebut. Fokus sanksi pidana ditujukan pada perbuatan salah yang telah dilakukan seseorang melalui pengenaan penderitaan agar yang bersangkutan menjadi jera. Fokus sanksi tindakan lebih terarah pada upaya memberi pertolongan pada pelaku agar ia berubah. Jadi sanksi pidana

\footnotetext{
${ }^{1}$ Ronny H. Soemitro, Metodologi Penelitian Hukum, (Semarang: Ghalia Indonesia, 1982), hlm. 9.

${ }^{2}$ Wikipedia Bahasa Indonesia, https://id.wikipedia.org/wiki/Sanksi , diakses tanggal 29 september 2018.

3 J.C.T. Simorangkir, SH., et.al "Kamus Hukum", (Sinar Grafika : Jakarta, 2007), hal. 152.

${ }^{4}$ Suharso dan Ana R, Kamus Besar Bahasa Indonesia edisi Lux,( Widya Karya: Semaranag,2014 ), hal 878 Kamus hukum

${ }^{5}$ Subekti , Kamus Hukum,(Pradnja Paramita : Jakarta,2005), hal. 98
} 
lebih menekankan unsur pembalasan (pengimbalan) dan merupakan penderitaan yang sengaja dibebankan kepada seorang pelanggar. Sedangkan sanksi tindakan bersumber dari ide dasar perlindungan masyarakat dan pembinaan atau perawatan si pembuat. Atau seperti dikatakan J.E.Jonkers bahwa sanksi pidana dititikberatkan pada pidana yang diterapkan untuk kejahatan yang dilakukan, sedangkan sanksi tindakan mempunyai tujuan yang bersifat sosial. Singkatnya, sanksi pidana berorientasi pada ide pengenaan sanksi terhadap pelaku suatu perbuatan, sementara sanksi tindakan berorientasi pada ide perlindungan masyarakat.

2. Pengertian Pidana dan Pemidanaan

\section{A. Pengertian Pidana}

Pidana berasal dari kata straf (Belanda), yang pada dasarnya dapat dikatakan sebagai suatu penderitaan (nestapa) yang sengaja dikenakan atau dijatuhkan kepada seseorang yang telah terbukti bersalah melakukan suatu tindak pidana. ${ }^{6}$ Dalam Kamus Besar Bahasa Indonesia Edisi II Cetakan IX, dicantumkan pengertian "pidana" yaitu hukum kejahatan (hukum untuk perkara kejahatan atau kriminal). ${ }^{7}$ Sudarto berpendapat bahwa pidana adalah penderitaan yang sengaja dibebankan kepada orang yang melakukan perbuatan yang memenuhi syarat-syarat tertentu. ${ }^{8}$ Sedangkan Roeslan Saleh menyatakan bahwa pidana adalah reaksi atas delik dan ini berujud suatu nestapa yang dengan sengaja ditimpakan Negara kepada pembuat delik. ${ }^{9}$ Hal senada juga dikemukakan oleh Andi Hamzah bahwa pidana dipandang sebagai suatu nestapa yang dikenakan karena melakukan suatu delik. Akan tetapi hal ini bukan merupakan tujuan akhir, melainkan hanya tujuan terdekat. Hal tersebut yang membedakan antara pidana dan tindakan karena tindakan juga dapat berupa nestapa tetapi bukan merupakan suatu tujuan. ${ }^{10}$

${ }^{6}$ Muladi dan Barda Nawawi Arief, Teori-Teori dan Kebijakan Pidana, (Bandung: Alumni,2005), hal.1 ${ }^{7}$ Departemen Pendidikan dan Kebudayaan, Kamus Besar Bahasa Indonesia, Edisi II Cetakan IX, (Jakarta:BalaiPustaka, 1997), hal 360

${ }^{8}$ Sudarto, Hukum dan Hukum Pidana (Bandung: Alumni, 1981), hal 125.

${ }^{9}$ Roeslan Saleh, Stelsel Pidana Indonesia, (Jakarta: Aksara Baru, 1978), hal 67

${ }^{10}$ Andi Hamzah, Asas-Asas Hukum Pidana, (Jakarta :Rineka Cipta,1994), hal. 27. 
Menurut Sudarto mengutip pendapat Hulsman, pidana adalah “menyerukan untuk tertib" (tot de orde roepen). ${ }^{11} \mathrm{Hal}$ ini selaras dengan pendapat yang disampaikan oleh G.P. Hoefnagels, sebagaimana dikutip oleh Muladi ${ }^{12}$ Ia tidak setuju dengan pendapat bahwa pidana merupakan suatu pencelaan (censure) atau suatu penjeraan (discouragement) atau merupakan suatu penderitaan (suffering). Pendapatnya ini bertolak pada pengertian yang luas, bahwa sanksi pidana adalah semua reaksi terhadap pelanggaran hukum yang telah ditentukan oleh undang-undang, sejak penahanan dan pengusutan terdakwa oleh polisi sampai vonis dijatuhkan. Jadi Hoefnagels melihatnya secara empiris, bahwa proses pidana yang dimulai dari penahanan, pemeriksaan sampai dengan vonis dijatuhkan merupakan suatu pidana. Dengan demikian tidak semua sarjana berpendapat bahwa pidana pada hakekatnya merupakan suatu penderitaan atau nestapa yang dikenakan terhada pelaku pelanggaran. ${ }^{13}$

Moelyatno membedakan istilah "pidana" dan "hukuman". Beliau tidak setuju terhadap istilah-istilah konvensional yang menentukan bahwa istilah"hukuman" berasal dari kata "straf" dan istilah "dihukum" berasal dari perkataan"wordt gestraft". Moelyatno menggunakan istilah yang inkonvensional, yaitu“pidana"untuk kata "straf" dan "diancam dengan pidana" untuk kata "wordgestraft". Hal ini disebabkan apabila kata "straf", diartikan "hukuman", maka kata "straf recht" berarti "hukum-hukuman". Menurut Moelyatno, “dihukum”berarti diterapi hukum, baik hukum perdata maupun hukum pidana. "Hukuman"adalah hasil atau akibat dari penerapan hukum tadi yang mempunyai arti lebih luas, sebab dalam hal ini tercakup juga keputusan hakim dalam lapangan hukum perdata. ${ }^{14}$ Hal di atas juga selaras dengan yang dikemukakan oleh Sudarto, bahwa"penghukuman" berasal dari kata "hukum" atau "memutuskan tentang hukumnya"

\footnotetext{
${ }^{11}$ Sudarto, Hukum dan Hukum Pidana, Op.Cit., hal. 81

${ }^{12}$ Muladi dan Barda Nawawi Arief, Loc.Cit.

${ }^{13} \mathrm{Ibid}$

${ }^{14}$ Moelyatno, Membangun Hukum Pidana, (Jakarta: Bina Aksara, 1985), hal. 40.
} 
(berechten). "Menetapkan hukum" untuk suatu peristiwa tidak hanya menyangkut bidang pidana saja, akan tetapi juga hukum perdata. ${ }^{15}$

Selanjutnya juga dikemukakan oleh Moelyatno bahwa istilah penghukuman dapat disempitkan artinya, yakni penghukuman dalam perkara pidana yang kerap kali sinonim dengan "pemidanaan" atau "pemberian/penjatuhan pidana"oleh hakim. Menurut beliau "penghukuman" dalam arti yang demikian mempunyai makna sama dengan "sentence" atau "veroordeling". Barda Nawawi Arief mengemukakan bahwa istilah "hukuman"kadang-kadang digunakan untuk pengganti perkataan "straf", namun menurut beliau, istilah "pidana" lebih baik daripada hukuman. Menurut Wirjono Prodjodikoro, kata "hukuman" sebagai istilah tidak dapat menggantikan kata "pidana", sebab ada istilah "hukum pidana" disamping"hukum perdata" seperti ganti kerugian berupa pembayaran sejumlah uang atau penyitaan barang. ${ }^{16}$

Sudarto menegaskan bahwa sejarah dari hukum pidana pada hakekatnya merupakan sejarah pidana dan pemidanaan. Pidana termasuk juga tindakan, bagaimanapun juga merupakan suatu penderitaan, sesuatu yang dirasakan tidak enak untuk dikenai. Oleh karena itu, orang tidak pernah ada henti-hentinya untuk mencari dasar, hakekat dan tujuan pidana dan pemidanaan,untuk memberikan pembenaran dari pidana itu sendiri. ${ }^{17}$

Barda Nawawi Arief yang mengutip pendapat Nigel Walker, mengetengahkan beberapa prinsip yang harus dipedomani dalam penggunaan hukum pidana sebagai berikut : ${ }^{18}$

1. Hukum pidana jangan digunakan semata-mata untuk pembalasana/retributif;

2. Jangan menggunakaan hukum pidana untuk memidana perbuatan yang tidak merugikan/membahayakan;

${ }^{15}$ Sudarto, Kapita Selekta Hukum Pidana,(Jakarta:Alumni, 2006), hal 72.

${ }^{16}$ Wirdjono Prodjodikoro, AsasAsas Hukum Pidana di Indonesia, ( Bandung :PT Eesco, 1976), hal. 1.

${ }^{17} \mathrm{Ibid}, \mathrm{hlm} .31$.

${ }^{18}$ Barda Nawawi Arief, Perkuliahan Pembaharuan Hukum Pidana, Program Magister Ilmu Hukum, Undip, Semarang, 2002. 
3. Jangan menggunakaan hukum pidana untuk tujuan yang dapat dicapai secara efektif dengan sarana-sarana lain yang lebih ringan;

4. Jangan menggunakaan hukum pidana apabila kerugian atau bahaya yang timbul lebih besar dari pada kerugian atau bahaya dari perbuatan atau tindak pidana itu sendiri;

5. Larangan-larangan hukum pidana jangan mengandung sifat lebih berbahaya daripada perbuatan yang akan dicegah;

6. Hukum pidana jangan memuat larangan larangan yang tidak mendapat dukungan dari publik;

7. Hukum pidana jangan memuat larangan atau ketentuan yang tidak dapat dilaksanakan atau dipaksakan.

\section{B.Pengertian Pemidanaan}

Pemidanaan adalah suatu proses atau cara untuk menjatuhkan hukuman/sanksi terhadap orang yang telah melakukan tindak kejahatan (rechtsdelict) maupun pelanggaran (wetsdelict). ${ }^{19}$ Teori pemidanaan merupakan upaya terakhir dan puncak dari proses penegakan hukum, penjatuhan pidana ini tidak bisa terlepas dari tugas hakim sebagai aparatur negara yang diberi wewenang oleh undang-undang untuk menjatuhkan sanksi pidana terhadap siapa saja yang melanggar aturan hukum.

Dalam hukum pidana di Indonesia, sistem pemidanaan secara garis besar mencakup 3 (tiga) permasalahan pokok, yaitu Jenis pidana (strafsoort), lamanya ancaman pidana (strafmaat), dan pelaksanaan pidana (strafmodus).

Akan tetapi dalam hal kasus pelanggaran Pemilu Meskipun penyelenggaraan penuntutan atas perkara pidana pemilu pada dasarnya menggunakan Kitab Undang-Undang Hukum Acara Pidana (KUHAP), (lex generalis), namun dalam undang-undang pemilu juga menentukan mekanisme atau hukum acaranya sendiri (lex specialis). Mengingat segala penyelesaian yang berkaitan dengan pemilu temasuk penegakan hukumnya dituntut harus diselesaikan dengan cepat, sehingga penyelenggaraan pemilu sebagai wujud pelaksanaan demokrasi dalam mengisi fungsi-fungsi kenegaraan yang masa

${ }^{19}$ Ibid, hlm 35 
jabatannya terbatas dapat dilaksanakan sebagaimana mestinya. Dalam hal ini sanksi pidana secara tegas terhadap pelanggaran Pemilu 2019 diatur dalam Undang-undang No 7 tahun 2017 Tentang Pemilu.

\section{E. PEMBAHASAN}

\section{Peran BAWASLU terkait Kasus Perindo}

Badan Pengawas Pemilihan Umum (disingkat Bawaslu) adalah lembaga penyelenggara Pemilu yang bertugas mengawasi penyelenggaraan Pemilu di seluruh wilayah Negara Kesatuan Republik Indonesia. Bawaslu diatur dalam pasal 95 Undang-Undang Nomor 7 Tahun 2017 Tentang Pemilihan Umum. Jumlah anggota Bawaslu sebanyak 5 (lima) orang. Keanggotaan Bawaslu terdiri atas kalangan professional yang mempunyai kemampuan dalam melakukan pengawasan dan tidak menjadi anggota partai politik. Dalam melaksanakan tugasnya anggota Bawaslu didukung oleh Sekretariat Jenderal Badan Pengawas Pemilihan Umum. ${ }^{20}$

Dalam melaksanakan tugas, Bawaslu berwenang:

a. menerima dan menindaklanjuti laporan yang berkaitan dengan dugaan adanya pelanggaran terhadap pelaksanaan peraturan perundang-undangan yang mengatur mengenai Pemilu;

b. memeriksa, mengkaji, dan memutus pelanggaran, administrasi Pemilu;

c. memeriksa, mengkaji, dan memutus pelanggaran politik uang;

d. menerima, memeriksa, memediasi atau mengadjudikasi, dan memutus penyelesaian sengketa proses Pemilu;

e. merekomendasikan kepada instansi yang bersangkutan mengenai hasil pengawasan terhadap netralitas aparatur sipil-negara, netralitas anggota Tentara Nasional Indonesia, dan netralitas anggota kepolisian Republik Indonesia; '

f. mengambil alih sementara tugas, wewenang, dan kewajiban Bawaslu Provinsi dan Bawaslu Kabupaten/Kota secara berjenjang jika Bawaslu Provinsi dan Bawaslu kabupaten kota berhalangan sementara akibat dikenai sanksi atau akibat lainnya sesuai dengan ketentuan

20 Wikipedia Ensiklopedia Bebas "https://id.wikipedia.org/wiki/Badan_Pengawas_Pemilihan_Umum, diakses tanggal 29 September 2018. 
peraturan perundang-undangan ;

g. meminta bahan keterangan yang dibutuhkan kepada pihak terkait dalam rangka pencegahan dan penindakan pelanggaran administrasi, pelanggaran kode etik, dugaan tindak pidana Pemilu, dan sengketa proses Pemilu;

h. mengoreksi putusan dan rekomendasi Bawaslu Provinsi dan Bawaslu KabupatenlKota apabila terdapat hal yang bertentangan dengan ketentuan peraturan perundangundangan;

i. membentuk Bawaslu Provinsi, Bawaslu Kabupaten Kota, dan Panwaslu $\mathrm{LN}$;

j. mengangkat, membina, dan memberhentikan anggota bawaslu Provinsi, anggota Bawaslu kabupaten/Kota, dan anggota Panwaslu LN; dan

k. melaksanakan wewenang lain sesuai dengan ketentuan peraturan perundang-undangan.

Sebagaimana kita ketahui bahwa salah satu tugas Bawaslu dalam Undang-undang ini adalah menerima dan menindaklanjuti laporan yang berkaitan dengan dugaan adanya pelanggaran terhadap pelaksanaan peraturan perundang-undangan yang mengatur mengenai Pemilu, terkait hal tersebut Bawaslu baru-baru ini mendapat laporan pelanggaran Pemilu yang dilakukan oleh partai Perindo.

Berdasarkan hasil temuan dan keputusan Gugus Tugas, yang terdiri dari KPU, Bawaslu, Dewan Pers dan KPI telah terjadi pelanggaran atas tayangan iklan partai Perindo sebelum masuk masa kampanye, yakni mengenai mars Perindo. Perindo merupakan salah satu dari empat partai baru yang lolos dalam verifikasi KPU sebagai peserta Pemilu 2019. Ketua Perindo, Hary Tanoesodibjo merupakan pemilik perusahaan media MNC Group yang membawahi RCTI, MNC TV, I News, dan Global TV. Keempat media tersebut kerap menayangkan iklan Perindo, salah satunya mars Perindo. Bagi penonton televisi di MNC Group (RCTI, Global TV, MNC TV dan beberapa kanal MNC di Indovision), penggalan lirik Mars Partai Persatuan Indonesia (Perindo) tadi pasti tak asing. Bahkan sedang hit di kalangan 
anak-anak, wajar mars ini membahana. Hary Tanoesoedibjo, sang pendiri Perindo, rutin beriklan di beberapa televisi miliknya itu sejak 2015.

Namun kampanye tersebut kini dipersoalkan Komisi Penyiaran Indonesia (KPI), yang sebenarnya bukan pertama kali memberi peringatan. Pada bulan Oktober 2016, KPI pernah menjatuhkan sanksi peringatan juga bagi empat televisi milik Hary. Di antaranya RCTI, MNC TV, I-News TV dan Global TV.Ke empat stasiun itu dinilai telah menayangkan iklan Perindo dengan intensitas tak wajar dan mengganggu kenyamanan publik. KPI menilai penayangan iklan Perindo telah melanggar kepentingan publik. Alasan yang sama ketika KPI memberikan sanksi pada tahun lalu. Sanksi KPI, menurut Hardly Stefano, komisioner KPI Pusat, didasari Pedoman Perilaku Penyiaran dan Standar Program Siaran (P3 \& SPS).Dalam pandangan Hardly, sebuah partai memiliki waktunya sendiri untuk berkampanye. Waktunya itu ditentukan oleh lembaga pemilihan umum, tidak bisa melakukan kampanye setiap hari. "(Mars Perindo ini) berkisar lima sampai 10 kali tayang (setiap harinya)," ujar Hadrly.

Sebagai gambaran masifnya iklan Perindo, Adstensity adalah sebuah platform penganalisa data iklan televisi. Dalam analisanya ternyata Mars Perindo mendapatkan angka fantastis.Terhitung, dari November 2015 hingga Januari 2016, iklan partai Perindo di MNC Group mencapai 1918 kali. Rincian iklan tersebut yakni RCTI (648 kali), MNCTV (630 kali) dan Global TV (640 kali). Nilai promosi iklannya mencapai Rp132 miliar. Di RCTI, iklan Perindo sering muncul di acara Gosip Go-Spot, Dashyat, FTV Pagi, FTV Siang dan Preman Pensiun. Sering juga pada waktu prime time. Misalnya di sela-sela sinetron Anak Jalanan dan Tukang Bubur Naik Haji. Lebih jauh, data terbaru sebulan terakhir dari 13 April 2017 hingga 12 Mei 2017 jumlah slot iklan Perindo yang tayang di televisi mencapai 443 kali. Detailnya, 213 iklan muncul di RCTI, 220 di MNC TV dan 220 lagi di Global TV. Dengan slot iklan yang mencapai 220-an itu, maka jika diratarata, setiap harinya iklan Perindo muncul sekitar 8-10 kali_di masing-masing televisi milik Hary. Tetapi Perindo tidak hanya beriklan di stasiun TV MNC 
Grup saja. Dalam periode 13 April-12 Mei 2017, iklan Perindo enam kali tayang di TVRI, tiga kali di Kompas TV dan sekali di SCTV. ${ }^{21}$

Maraknya iklan Perindo sejak lama memang membuat orang tua_resah. Pasalnya banyak anak-anak, yang belum cukup usia, hafal lirik mars dalam iklan itu. bahkan ada anak yang ketika di tanya apa lagu kebanggsan, anak tersebut menyanyikan lagu Mars Perindo ini. Berikut lirik Mars Perindo sepertinya memang dibuat serius. Jika diperhatikan detail, kalau huruf di awal setiap bait disatukan, maka tertera dua kata:

\section{MARS PERINDO.}

Marilah Seluruh rakyat Indonesia

Arahkan pandanganmu ke depan

Raihlah mimpimu bagi nusa bangsa

Satukan tekadmu untuk masa depan

Pantang menyerah itulah pedomanmu

Entaskan kemiskinan cita-citamu

Rintangan tak menggentarkan dirimu

Indonesia maju sejahtera tujuanmu

Nyalakan api semangat perjuangan

Dengungkan gema nyatakan persatuan

Oleh PERINDO... oleh PERINDO...

Jayalah Indonesia!

Atas dasar inilah KPI melaporkan Mars Perindo karena selain membuat resah, jelas sekali Mars Perindo ini merupakan pelanggaran pemilu karena memang belum saatnya bagi parpol untuk berkampanye.Terkait pelanggaran yang dilakukan Perindo, Bawaslu berdasarkan wewenang yang ada padanya sebagaimana tercantum dalam pasal 95 ayat (1) Undang-undang No 7 tahun 2017 Tentang Pemilu , berbunyi “ bahwa Bawaslu berwenang untuk menerima dan menindaklanjuti laporan yang berkaitan dengan dugaan adanya pelanggaran terhadap pelaksanaan peraturan perundang-undangan

21 Heru Triyono “ KPI hentikan Mars Perindo berkumandang? "https://beritagar.id/artikel/berita/kpihentikan-mars-perindo-Berkumandang, diakses tanggal 28 September 2018. 
yang mengatur mengenai Pemilu. Dalam ayat (2) dikatakan Bawaslu berwenang untuk melakukan pencegahan dan penindakan terhadap:

1. pelanggaran Pemilu; dan

2. sengketa proses Pemilu;

Adapun pencegahan pelanggaran pemilu yang seharusnya dilakukan Bawaslu sejalan dengan Tugas Bawaslu yang terdapat dalam pasal 93 huruf b Undang-undang No 7 tahun 2017 Tentang Pemilu yang berbunyi: Bawaslu bertugas untuk:

b. melakukan pencegahan dan penindakan terhadap:

1. pelanggaran Pemilu; dan

2. sengketa proses Pemilu;

Sedangkan dalam pasal 94 ayat (2) dikatakan bahwa "dalam melakukan pencegahan pelanggaran Pemilu dan pencegahan sengketa proses Pemilu sebagaimana dimaksud dalam Pasal 93 huruf b, Bawaslu bertugas:

a. menerima, memeriksa dan mengkaji dugaan pelanggaran Pemilu;

b. menginvestigasi dugaan pelanggaran Pemilu;

c. menentukan dugaan pelanggaran administrasi Pemilu, dugaan pelanggaran kode etik Penyelenggara Pemilu, danTatau dugaan tindak pidana Pemilu; dan ',

d. memutus pelanggaran administrasi Pemilu.

Bila dilihat dari pasal 93,94 dan 95 Undang-undang ini peran Bawaslu adalah untuk menerima, memeriksa dan mengkaji serta menindaklanjuti laporan dugaan pelanggaran pemilu terkait kasus mars Perindo. Sebagai bukti pelaksanaan dari UU tersebut baru-baru ini Bawaslu memanggil HTR / Harry Tanoe Soedibyo selaku pemilik dari MNC Group untuk meminta keterangan mengenai maksud ditayangkannya mars partai Perindo di empat stasiun TV milik HTR. Jika memang sudah memenuhi unsur pelanggaran kampanye maka Bawaslu memiliki wewenang untuk memberikan sanksi pada HTR selaku pemilik stasiunTV. 


\section{Penerapan sanksi terhadap Perindo}

Dalam hal pelanggaran waktu kampanye yang dilakukan Perindo dengan menayangkan Mars Perindo di empat stasiun TV milik HTR maka Badan Pengawas Pemilu (Bawaslu) menyatakan, Partai Perindo terbukti melanggar Undang-Undang Pemilu. Perindo terbukti beriklan selama Nov 2015-5 Maret 2018 di stasiun televisi MNC grup yang juga milik ketua umum partai itu sebelum masuk masa kampanye, September mendatang. Dalam hal ini ketua Bawaslu RI Abhan menjelaskan, Partai Perindo melanggar Pasal 492 Undang-Undang Nomor 7 Tahun 2017 tentang Pemilihan Umum. Menurut Abhan "Dari kesimpulan yang sudah kami lakukan, memang ditemukan bahwa unsur kampanye melalui media elektronik memang terbukti," ucap Abhan di Gedung Bawaslu RI, Jalan MH Thamrin, Jakarta Pusat, Jumat (23/3/2018). ${ }^{22}$ Pada akhirnya Bawaslu, Polisi dan Jaksa menyimpulkan bahwa, terkait dengan status temuan atas tindak pidana pemilu, Perindo terbukti melanggar pasal iklan kampanye di luar jadwal (sesuai) pasal 492," Adapun bunyi pasal 492 Undang-Undang Nomor 7 Tahun 2017 tentang Pemilihan Umum adalah :

Pasal 492

Setiap orang yang dengan sengaja melakukan Kampanye Pemilu di luar jadwal yang telah ditetapkan oleh KPU, KPU Provinsi, dan KPU 1(abupaten/Kota untuk setiap Peserta Pemilu sebagaimana dimaksud dalam Pasal 276 ayat (2), dipidana dengan pidana kurungan paling lama I (satu) tahun dan denda paling banyak Rp12.000.000,00 (dua belas juta rupiah).

Namun, partai baru yang diketuai Harry Tanoesoedibjo tersebut tidak dapat dikenai hukuman pidana meski terbukti melakukan pelanggaran. Hal ini dikarenakan adanya syarat formil yang belum terpenuhi. Yakni, Sentra Penegakan Hukum Terpadu (Gakkumdu) yang terdiri dari Bawaslu, Kepolisian dan Kejaksaan belum terbentuk. Sementara, Bawaslu dalam

${ }^{22}$ Yuinizfira Putri Arifin Wijaya, Terbukti Langgar UU Pemilu, Perindo Tidak Bisa Dikenakan Sanksi, https://www.liputan6.com/news/read/3400636/terbukti-langgar-uu-pemilu-perindo-tidak-bisa-dikenakan-sanksi diakses tanggal 30 September 2018. 
kasus dugaan tindak pidana pemilu, tidak bisa berdiri sendiri untuk menindaklanjuti sebuah perkara. Sehingga Bawaslu menyatakan Perindo belum bisa dilanjutkan ke tingkat penyidikan, karena ada syarat formil yang belum terpenuhi. Dalam pasal 1 Undang-undang No 7 Tahun 2017 tentang Pemilu dijelaskan bahwa Penegakan Hukum Terpadu yang selanjutnya disebut Gakkumdu adalah pusat aktivitas penegakan hukum tindak pidana Pemilu yang terdiri atas unsur Bawaslu, Bawaslu Provinsi, dan/atau Bawaslu Kabupaten/Kota, Kepolisian Negara Republik Indonesia, Kepolisian Daerah, dan atau Kepolisian Resor, dan Kejaksaan Agung Republik Indonesia, Kejaksaan Tinggi, dan/atau Kejaksaan Negeri.

Jelas sekali disini bahwa yang dapat melakukan penegakan hukum terhadap pelanggar pemilu adalah Sentra Gakkumdu, ementara Sentra Gakkumdu untuk pemilu belum terbentuk karena masih menunggu SK Kepolisian. Sehingga terhadap Perindo tidak dapat dikenakan sanksi pidana.

\section{F. KESIMPULAN}

1. Berdasarkan hasil temuan dan keputusan Gugus Tugas, yang terdiri dari KPU, Bawaslu, Dewan Pers dan KPI telah terjadi pelanggaran atas tayangan iklan partai Perindo sebelum masuk masa kampanye, yakni mengenai mars Perindo. Perindo merupakan salah satu dari empat partai baru yang lolos dalam verifikasi KPU sebagai peserta Pemilu 2019. Ketua Perindo, Hary Tanoesodibjo merupakan pemilik perusahaan media MNC Group yang membawahi RCTI, MNC TV, I News, dan Global TV. Keempat media tersebut kerap menayangkan iklan Perindo, salah satunya mars Perindo. Bila dilihat dari pasal 93,94 dan 95 Undang-undang ini peran Bawaslu adalah untuk menerima, memeriksa dan mengkaji serta menindaklanjuti laporan dugaan pelanggaran pemilu terkait kasus mars Perindo. Sebagai bukti pelaksanaan dari UU tersebut baru-baru ini Bawaslu memanggil HTR / Harry Tanoe Soedibyo selaku pemilik dari MNC Group untuk meminta keterangan mengenai maksud ditayangkannya mars partai Perindo di empat stasiun TV milik HTR. Jika memang sudah memenuhi unsur pelanggaran kampanye maka Bawaslu mmilik wewenang untuk memberikan sanksi pada HTR selaku pemilik stasiunTV. 
2. Partai Perindo melanggar Pasal 492 Undang-Undang Nomor 7 Tahun 2017 tentang Pemilihan Umum. Namun, partai baru yang diketuai Harry Tanoesoedibjo tersebut tidak dapat dikenai hukuman pidana meski terbukti melakukan pelanggaran. Hal ini dikarenakan adanya syarat formil yang belum terpenuhi. Yakni, Sentra Penegakan Hukum Terpadu (Gakkumdu) yang terdiri dari Bawaslu, Kepolisian dan Kejaksaan belum terbentuk

\section{Daftar Pustaka}

Andi Hamzah, Asas-Asas Hukum Pidana, Jakarta :Rineka Cipta,1994.

Barda Nawawi Arief, Perkuliahan Pembaharuan Hukum Pidana, Program Magister Ilmu Hukum, Undip:Semarang, 2002.

Departemen Pendidikan dan Kebudayaan, Kamus Besar Bahasa Indonesia, Edisi II Cetakan IX, Jakarta:Balai Pustaka, 1997.

J.C.T. Simorangkir, SH., et.al "Kamus Hukum", Sinar Grafika : Jakarta, 2007.

Moelyatno, Membangun Hukum Pidana, Jakarta: Bina Aksara, 1985.

Muladi dan Barda Nawawi Arief, Teori-Teori dan Kebijakan Pidana, Bandung: Alumni,2005.

Roeslan Saleh, Stelsel Pidana Indonesia, Jakarta: Aksara Baru, 1978.

Ronny H. Soemitro, Metodologi Penelitian Hukum, Semarang: Ghalia Indonesia, 1982.

Sudarto, Hukum dan Hukum Pidana, Bandung: Alumni, 1981.

Sudarto, Kapita Selekta Hukum Pidana,Jakarta:Alumni, 2006.

Suharso dan Ana R, Kamus Besar Bahasa Indonesia edisi Lux, Widya Karya: Semarang, 2014

Wirdjono Prodjodikoro, AsasAsas Hukum Pidana di Indonesia, Bandung :PT Eesco, 1976.

Heru Triyono " KPI hentikan Mars Perindo berkumandang? "https://beritagar.id/artikel/berita/kpi-hentikan-mars-perindo-Berkumandang , diakses tanggal 28 September 2018.

Wikipedia Bahasa Indonesia, https://id.wikipedia.org/wiki/Sanksi , diakses tanggal 29 september 2018.

Wikipedia Ensiklopedia Bebas "https://id.wikipedia.org/wiki/Badan_Pengawas_Pemilihan_Umum, diakses tanggal 29 September 2018.

Yuinizfira Putri Arifin Wijaya, Terbukti Langgar UU Pemilu, Perindo Tidak Bisa Dikenakan Sanksi, https://www.liputan6.com/news/read/3400636/terbuktilanggar-uu-pemilu-perindo-tidak-bisa-dikenakan-sanksi , diakses tanggal 30 September 2018.

Indonesia, Undang-undang No 7 Tahun 2017 Tentang Pemilihan Umum, Tambahan Lembaran Negara (TLN) Nomor 6109. 